\title{
The Image Of Wolio Women In People's Folklore: a Sociofeminical Study
}

\author{
Sumiman Udu ${ }^{1}$, Suryanti ${ }^{2}$, Anna Nurawalia ${ }^{3}$, Dinna Dayana La Ode Malim ${ }^{4}$, Laxmi ${ }^{5}$, \\ Adolina Felomena Lewaan ${ }^{6}$ \\ FKIP of Universitas Halu Oleo ${ }^{1}$, FKIP of Univeritas Muhamadiah Buton ${ }^{2}$, FKIP of \\ Universitas Muslim Buton ${ }^{3}$ Law Faculty of Universitas Dayanu Ikhsanuddin, Baubau ${ }^{4}$, \\ Cultural Science Faculty of Universitas Halu Oleo, Kendari ${ }^{5}$, Universitas Cendrawasih Papua ${ }^{6}$ \\ \{sumimanudu75@gmail.com¹, suryanti042516@gmail.com², annanurawalia@umubuton.ac.id³, \\ dinnadayana@gmail.com ${ }^{4}$, inasamosir@gmail.com $\left.{ }^{6}\right\}$
}

\begin{abstract}
As one of the cultures in Indonesia, Wolio has a collective memory which emphasizes about their woman. Through their various folk tales, women are depicted as honorable creatures, as well as beings that neglected by culture. Therefore, this study aimed to describe the image of women in folklore. This research was a descriptive qualitative research and focuses on the image of women. This study used a socio-feminism approach. The data analysis technique used the image theory proposed by A. Ruthven which highlight on how women are imaged in the text, how they should be read, and tries to unravel the ideology which underlies each of these images. The results indicated that various folk tales existed in Wolio in which highlighted that not all women were imaged as a strong or independent image, but quite often they were made subordinated by men. Based on a view of feminist, it is found that the image of Wolio women must be explained as women who are subordinated according to the various folk stories. Meanwhile, from the uncovering of her ideology, it is able to be explained that cultural and political influences have made the various images of Wolio women subordinated in culture and politics. The various negative treatments experienced by Wolio women are conveyed by this study as a representation of the image through the story. On top of that, the image of women is manifested in physical, psychological, helpless, resigned to circumstances, housewives, loyalty, babysitting, domestic, husband's companion, and social.
\end{abstract}

Keywords: Image; Wolio Women; Folktale; Socio-Feminists

\section{Introduction}

Folklore is a collective memory that contains the various moral orders that exist in the owner's community. Folklore can reflect a variety of social relationships in society, including the relationship between men and women. As one of the centers of civilization in the central region of Indonesia, Wolio has a strategic role in building various images of women in his 
civilization. In fact, in its history, Buton was led by two queens, namely Ratu Wakaaka and Ratu Bulawambona (Desi Sari, Sumiman Udu, 2019). These various stories are told in the oral history of the Butonese people, although some of them have already been written. On the other hand, the existence of women is also imaged as a second class creature who is always subordinated in relation to men. Here, we can see the dynamics of the image of women in the Buton oral tradition. Even in the stories of Wa Ode Iriwondu, Wa Ndiu-ndiu, and several other stories, women are often used as objects of male torture (Udu, 2019b).

Based on these various cultural phenomena, the Buton oral tradition (folklore) is an interesting cultural construction space to see the position of women in Buton society, on the other hand, the young generation of Buton today has questioned many problems of norms in their culture which has been the most effective space for cultural construction. Even in one of the Wakatobi songs entitled Potumpu Wowine, someone dares to question if we can propose even though it is a woman, so please apply to the man of my choice. This is a space for cultural dialogue that must revisit various images of women in various Buton oral traditions. Therefore, this research will focus on how the image of Wolio women in various oral traditions (folk tales) that exist (Udu, 2019b).

By understanding the image of women in various Wolio folk tales, it is hoped that it can become an important source of information to increase knowledge about Wolio women, as well as being one of the considerations in empowering Wolio women. With the results regarding the image of Wolio women from a socio-feminist perspective, it will be easier for us to understand how Wolio women can take various roles, both in their domestic and public roles in the future. They can be one of the strengths of modern development, but they must also remain concentrated on their domestic role, because that is the role of Wolio women as the essence of teachers for their children, the first teacher to create a quality young Buton generation (Udu, 2010). Those who become women have three aspects of Wolio women, especially in their role as empress, 1) as teachers for their children, 2) as guardians of the husband's safety, and 3) maintaining welfare (Udu, 2011).

The amalgamation of the results of imagination and the thought of writing about the life of social problems that exist in society is expressed in literary works including old literature such as folk tales. Folklore, as a collective memory and belonging to the collective community supporters see (Isenberg \& Abrams, 1954). As a collective property, the folklore is a reflection of the social reality of the supporting communities. Whatever is in the folklore is the collective property of the community, the imagination and the results of these thoughts produced in oral literary works are spaces for the collective imagination of the supporting communities (Hindaryatiningsih, 2016).

So in the Wolio folklore, various images of women are collective memory spaces of the Wolio community that store their various collective memories, as well as cultural spaces that store various morals that govern the relationship of men and women. The problems that occur in society are processed by the author (modern literature) and give birth to a literary work that reflects on things that usually occur in Wolio. Literary work is a creation that must be lifted from social reality. However, the works of satra can also be mixed with the ideas of the author or narrator of the folklore. Not too rigid with existing social realities. Literary works are increasingly attractive to the audience when combined with the writer's thoughts. Every folklore telling cannot be separated from the subjectivity of the storyteller.

According to Gafur (2015), although on the other hand, a woman is often used as an object in everything. Even women are considered as "second class humans" where the first position is occupied by another human named male. In the Bibble tradition, it is stated that women were created from Adam's rib to be friends with him. Therefore, women are second creation; 
she is just a being created from and for man. In addition, women also have the image of being seductive and close to the devil, because at the beginning of his creation, woman (Eve) seduced Adam to eat the fruit of the khuldi. Such imagery must be seen again so that we can understand the role of women in the current industrial 4.0 era.

According to Isma (2016), men and women are equal before Allah SWT (Das Sollen). However, stereotypes, discrimination and violence against women are ubiquitous. The position of women according to Serat Yusuf as literature that is born from a gender-biased social construction places women unequally. This condition can also be found in various Wolio folk tales. There are even some folk tales of Wolio that portray women as the source of the problem as in the Samit religious teachings. This is a space to re-question these various images, so that if you look at it from Ruthven's perspective, it will be something interesting to read, especially how are women portrayed in literature? How can we read it? and can dismantle the ideology that underlies each of these images.

Feminism is described as a conflict that demands equality between men and women. This equality of degree and position has many influences in people's lives. Generally, people think that women need education, but at present this is very much fought by women as well.

Women are also a movement that demands equality and justice for both political, social and economic rights between women and men without any discrimination. In addition, feminism is also a movement for the emancipation of women, this movement is loudly voiced about improving the emancipation movement and rejecting the difference in degrees between men and women. Therefore, the socio-feminist movement aims to increase the position and status of women so that they are equal to the position of men. Feminism's struggle to achieve this goal includes many ways. One of them is getting the same rights and opportunities as men. In the socio-feminist study it is directed to be able to see the various images of women that exist in various forms of text, including in the context of this article the images of women in various Wolio folk tales. Through a socio-feminist approach, this research aims to understand the various images of women in Wolio various folk tales, and what it should be like to read each of these images. Furthermore, through careful reading, it will be directed to dismantle the ideology that built the image, so that we can understand why the image of women is formed in various Wolio folk tales.

\section{Methods}

This research was conducted using a socio-feminist approach to see how women are imaged in Wolio folklore. Furthermore, the data were seen in a socio-feminist perspective, so that each image could be read in two circumstances in terms of the domestic where women play several roles including as the children, as wives, as mothers, and also as business and political friends. In addition, these images were seen in the role of women when they were in public space. In addition, socio-feminism also exposed the ideology behind every image of women in Wolio folklore (Brown et al., 1971). Therefore, the data presented in this study were library data and based on the field data, thus, the data collection techniques were carried out through library research or literature review and field research by using an observation. The data analysis technique were adjusted to the socio-feminist principles as stated by Ruthven that the data would be analyzed by reading the image of women in folklore, then it would be read in a feminist perspective and the ideology would be exposed which underlies each of these images. 


\section{Results}

The results of this study indicated that the image of Wolio women in various Wolio folk tales can be described from two spaces including a) the domestic space and b) the role of women in the domestic space. In her role in these two spaces, Wolio women are imaged in various folk tales with various forms of imagery, so it is necessary to read them carefully and also to dismantle each of these images, so that readers can understand these various images from a socio-feminist perspective. In the following, the results of this study will be described as follows.

\subsection{Image of Wolio Woman in Domestic Room}

In several folk stories in Wolio society, women are imaged both physically and psychologically. This image can be seen in a domestic context as well as in a public context. In the domestic space, the psychological and physical image of women can be seen in their roles as mothers, children, and in their roles as wives (Udu, 2010). Therefore, the various forms of imaging will be described as follows.

\subsubsection{Image of Woman as Mother}

The role of Wolio women as mothers in the domestic space becomes an image that can be found in various existing folk tales. In the folklore of Wakaaka, for example, Wakaaka is portrayed as a physically beautiful woman (Udu, 2019a). She is also imaged as a woman who has good leadership experience. Likewise with Bulawambona, both of them are portrayed as beautiful women. As a mother, Wakaaka is a mother who loves her children and bequeaths her throne to her son Bulawambona. He is able to educate his son to become king. In the Betena Tombula folklore, the story of the Butonese people explains that in order to continue his leadership, he passed on his leadership to his son Bulawambona.

In her image as a mother, Wolio woman can also be seen from her responsibility as a mother who is willing to sacrifice to look for fish when her children eat fish. When her husband is angry, as a mother who is responsible for maintaining welfare, she is willing to look for fish in the sea, until she turns into a mermaid. In the wandiu-diu story, the woman of Wolio who acts as a mother gives education to Buton's children to be responsible for what her children do at home. This is a form of the image of Wolio women who dare to take responsibility whatever the risk. In fact, several stories are told that in her role as a mother, Wolio women are both mothers and teachers of the country (children and women). They are also protectors of the country (children and women). Through their amala / good behaviors (ritual/ local custom) and abilities which they can protect the children and the women in the country.

Even in several other stories, in her role as a mother, Wolio women are portrayed as having the responsibility of being a mother who is breastfeeding her children. This kind of imagery is a form of branding a Wolio woman who has responsibility as a woman who has responsibility for the health of their children.

"Ibunya memberikan ikan Mas kepada anak-anaknya, akan tetapi anak itu tidak mau"

"Dia mengelus-elus kedua anaknya tersebut dan disusuinya La Mbatambata sampai kenyang. Di cium dan dipeluknya anak anaknya sepuas-puasnya"

"Bukan mereda marahnya malah tambah marah dan tanpa sadar mengambil perkakas tenun untuk memukul istrinya sampai patahpatah perkakas tenun itu dan menyebabkan istri babak belur, dan meneteskan darah dari hidungnya" 
"The mother gave the goldfish to the children, but the child did not want to"

"She stroked the two children and fed La Mbatambata until they were full. He kissed and hugged his children as much as he wanted"

"It did not subside his anger, instead he became even more angry and unconsciously took a loom to beat his wife until it broke the loom and caused the wife to be battered, and had blood dripping from her nose"

Each paragraph above falls into the category of proairetic code or action code because there is an action from the figure of the mother in this story, namely giving goldfish to her child to eat. In this story, the image of Wolio woman is depicted as a wife and a mother who mostly stays in the house taking care of the children and taking care of the kitchen.

In the paragraph "She stroked her two children and fed La Mbatambata until they were full. He kisses and hugs his children as much as he wants ", found a semic code because it describes the value of a mother's love for her child where the essence of a mother is to breastfeed her child then give love by kissing and hugging. So, the child feels the love from the mother. This is also a manifestation of the noble values of Wolio women in their household. In the context of the family, the relationship between the child and the mother shows that as a mother, Wandiu-diu is responsible for the health of her children. This shows that Wolio women have the responsibility of being a mother who loves herself and her children. Even in the Buton sultanate government system, Buton women must be able to look after and protect their children.

In the paragraph "Not subsiding his anger, he became even more angry and unconsciously took a loom to beat his wife until it broke the loom and caused the wife to be battered, and dripping blood from her nose", it is also categorized as proairetic code because there is a sequence of actions or a series of actions that occur. Interrelated, starting from the husband getting angry then taking a weaving tool then beating his wife until she drips blood from her nose.

In this story, the image of Wolio woman is described as a patient wife, even though she has been abused or even injured. However, in this modern era, along with the development of the era, most Wolio women have received education so that they are able to provide protection for themselves in the form of legal protection, psychology, and so on, if they receive forms of oppression, verbal or non-verbal violence. verbal, and or forms of discrimination. Based on an oral interview with one of the humanists and historians, Wolio Imran Kudus, there is a fact that on the other hand there are still some Wolio women who still maintain old customs, such as what happened in the Wandiudiu story long after or before $1610 \mathrm{AD}$ during the reign of the Buton sultanate.

"Sore hari, matahari pulang ke peraduan. Suami Wandiu-Diu pulang pula ke rumah kediamannya. Di muka pintu, Wandiu Diu berdiri menyambut. Membantu mengangkati beberapa ikat jagung dan ubi kayu yang dibawa suaminya dari kebun. Tiba-tiba saja dari balik dapur rumah reot mereka suaminya berteriak lantang memanggilnya keras sekali: "Diu......!!!". Wandiu-Diu tersentak kaget. Ia terkesiap bergegas menujui muasal datang suara itu, di dapur. "Siapa yang berani mengambil ikan tengiri kering saya, bukankah sudah kuingatkan jangan sekali-kali menyentuhnya?!!" teriak suaminya dalam amarah. "Anu Ama..,Lambata-Mbata tak mau memakan apapun, hanya meminta sedikit itu saja. Ia terus menangis, saya kasihan dan tak sampai hati melihatnya terus menangis" Jawab WandiuDiu dalam tunduk, takut menantang mata suaminya. "Jadi kau tak lagi patuh pada saya? Berani kau melawan saya sekarang?!!” Amarah suaminya membuncah meluap-luap seperti air yang dididihkan. Matanya melorot tajam, dua alis tebalnya seperti saling mengait 
bersambungan. "Tidak, tidak semasekali. Bagaimana saya tidak patuh pada suami sendiri, bagaimana mau saya melawan pada suami sendiri? Wanita, sekuat-kuat bagaimanapun tetap saja tak bisa menandingi kuat perkasanya lelaki”. Wandiu-Diu memelas. Ia jatuh terduduk, nyalinya ciut, surut meriut seperti keong. Ia duduk terpekur meremas lantai, memelas-melas minta dibelas, minta dikasihi. Dalam duduk itu ia membayangkan tangan kasar suaminya akan kembali datang menubruk mukanya. Dan benar saja sebuah tamparan dari telapak yang kasar melayang secepat kilat mengenai mukanya. Ia disepak, ditendang didorong-dorong pula"

"In the afternoon, the sun returns to bed. Wandiu-Diu's husband also returned to his residence. At the door, Wandiu Diu stood welcoming. Helped lift several bunches of corn and cassava that her husband brought from the garden. Suddenly from behind the kitchen of their rickety house her husband shouted out loud calling her very loudly: "Diu ... !!!". Wandiu-Diu gasped in surprise. He gasped in a hurry to acknowledge the sound coming from in the kitchen. "Who dares to take my dried mackerel, haven't I warned you not to touch it? !!" cried her husband in anger. "Anu Ama .., Lambata-Mbata doesn't want to eat anything, just asks for a little of it. She keeps on crying, I feel sorry for her and I don't have the heart to see her continue to cry "Wandiu-Diu answered in submission, afraid to challenge her husband's eyes. "So you are no longer obedient to me? Dare you fight me now? !! " Her husband's anger was bubbling over like boiling water. His eyes were sharply drooping, his two thick eyebrows seemed to link together. "No, not once in a while. How can I disobey my own husband, how can I fight against my own husband? A woman, no matter how strong, cannot match the mighty power of a man ". Wandiu-Diu is pitiful. He fell to his knees, shrinking his guts, shrinking back like a snail. He sat there squeezing the floor, begging for a clarification, asking to be loved. While sitting there she imagined that her husband's rough hand would come back and hit her face. And sure enough a slap from the rough palm flew as fast as lightning hit his face. He was kicked, kicked and pushed too"

This paragraph also describes the assertiveness and arrogance of Wandiudiu's husband who stipulates that the fish that has been prepared for him cannot be eaten or touched by other people even by his own children. In this story, the image of Wolio woman is once again well illustrated that obedience to her husband is the main thing. Because in the perspective of Buton society, Buton women have to serve their husbands. However, in a sociofeminist context, obedience to husbands must be based on truth values that are mutually agreed upon by a husband and wife. This is as stated by Anthony Giddens who said that modern women must be born in a democratic family, where everything must be decided in the form of dialogue (Udu, 2010).

"Merasa telah diperlakukan kasar berlebihan, bangkit keberanian Wandiu-Diu. Ia berdiri dari duduknya, melawan pandang suaminya yang memelototinya. Tapi pukulan terus datang mengenai badan tubuhnya. Sebilah dayung dari kayu yang keras patah berantakan di punggungnya. Ia kemudian melompat turun dari rumahnya. Lari ke laut membuang diri, menenggelamkan badan tubuhnya di gulungan ombak laut musim barat yang ujung buihnya meliuk-liuk setinggi gunung besarnya membanting diri ke pantai"

"Feeling that he had been treated too harshly, Wandiu-Diu got up his courage. She rose from her seat, against her husband's glaring eyes. But the punches continued to hit his body. A hard wooden oar fell apart on its back. He then jumped down from his house. Running to the sea to throw himself away, drowning his body in the rolls of the west monsoon sea waves whose foam ends twisting as high as a huge mountain slamming itself onto the beach"

In the next paragraph, another image of Wolio woman is also represented from Wandiudiu's story. Wolio women, like women in general, also have the right to freedom, 
especially the freedom to express their grief or seek self-protection. This was also expressed by Wandiudiu by drowning himself in the beach. This shows that the image of Wolio women is depicted as women who have actually fought, even though this was done indirectly. Wandiu-ndiu wanted to go to sea as a form of resistance to his culture. Buton folklore portrays the image of women who rebel against their culture.

\subsubsection{Women as A Child}

In Wolio folklore, children are portrayed as independent and beautiful children. In the folklore of Wa Samba-samba paria, for example, the characters of wa dhiki-dhiki panamba and wa samba-samba mparia are independent children when they have been abandoned by their parents. Wolio's daughter is described as a child who is obedient to both parents and the teachings of Islam. This is indicated by the many forms of pamali that protect Wolio children by ruling them in a good regulations through several forbidden aspects in life, especially for girls. In the study of Wandiudiu folklore, the researcher found that the image of Wolio's woman as a child was also depicted in her folk tales. This can be seen in the cultural and educational aspects. In the days of the kingdom to modern times like today, there were some Wolio daughters who decided to continue their bachelor's, master's and doctoral degrees and even took the scholarship path at home and abroad. On the other hand, there are still most of Wolio's daughters who choose to stay in their hometown. The image of Wolio woman as a child is depicted as a child who obeys customary rules, for example by being obliged to participate in posuo activities, religious teachings, for example by obliging to attend recitation classes for followers of the Islamic religion, and parental advice, for example by following pamali rules which are recommended and prohibited. for the good of a daughter Wolio.

Cultural codes indicate types of knowledge. Such as sociology, psychology, and others. Cultural code refers to a set of knowledge that supports the text being read. The following is the cultural code in the analysis of the Wandiu-ndiu folklore which has a close relationship with the image of Wolio girls or the images and speech acts of children of Wolio descent:

"Maka berangkatlah Ibu Wa Turungkoleo meninggalkan anaknya, mulai dari depan pintu dia merobekrobek sarung dan bajunya lalu dijatuhkan sepanjang jalan agar anak-anaknya muda menemukannya bila anak-anaknya mencarinya besok lusa."

"So then Mrs. Wa Turungkoleo left her child, starting from the front door she tore her sarong and clothes and then dropped them all the way so that her young children would find her if their children were looking for her the day after tomorrow."

This paragraph is categorized as a cultural code because there is a psychological element that we can see where a mother feels affection for her child, even though the mother will go far away but she still gives signs or directions to her child so that they can meet again.

"Berkatalah dia kepada anaknya yang tua 'sayangilah adikmu, jaga dan pelihara dia dengan baik ! berkata pula dia kepada Lambatambata, andai kata engkau Lambatambata tidak ingin makan ikan garam bapakmu tidaklah aku menderita seperti ini."'

"He said to his old son, 'love your brother, take care of him and care for him well! He also said to Lambatambata, if you say that Lambatambata does not want to eat your father's salt fish, I will not suffer like this."

In this, there is a depiction of a Wolio's daughter, namely in a brotherly relationship, an older sister must look after and take good care of her younger sister. It can be seen in the mother's direct speech to her eldest child. food then we will not be separated, my son "

This is reinforced by the emergence of the next sentence: "Just when he came out of the fence he saw the torn cloth that belonged to his mother, so he said to his younger brother, if yesterday you didn't eat your father's salt fish it wouldn't be like this." 
In these two sentences (1) "While Wandiudiu was breastfeeding Lambatambata, he said" If only you aren't picky about food, we will not be separated, my son "(2)" Just got out of the fence he saw the torn cloth that belonged to his mother, then He said to his younger brother, if yesterday you had not eaten your father's salt fish it would not have been like this." Researchers found also the meaning of adherence to parents. A child should obey the orders of both parents as long as those orders are good for the benefit of all. Because there will be consequences if there are rules that are violated.

Thus, in her role as a daughter, Wolio has a responsibility to her family. This shows that the image of Wolio woman has room to serve her mother. A Wolio daughter should have space to express herself, so that they have the opportunity to become a woman who has the freedom to determine her future, and can synergize with other family members. The culture of Wolio (Buton) must be returned to protect women and provide opportunities for women to have a public space like the Buton women in the past. They must receive education from their mother as the first teacher in the Wolio family.

\subsubsection{Woman as A Wife}

One of the data from the Wolio Wandiudiu folklore, which has been translated from Wolio into Indonesian, is then analyzed using a socio-feminist approach and also looking at the coded form in the story which focuses on the Images of Wolio women. The researcher then examined the data based on the following aspects: (1) Identifying the image of Wolio women depicted in Wandiudiu's story. The image of women represented in Wandiudiu's story can be seen from their roles and activities in (a) public, (b) domestic, (c) social and religious, (d) education and morals, (e) recreation, (f) ownership, and (g) access control and decision making. The image of women represented has a close relationship with the culture and traditions of women in Wolio society.

Based on the research results, several forms of code were found in the Wandiuddiu folklore. This folklore also has an explicit and implied message. In addition, the results of this semiotic analysis also reveal several social functions for this folklore. The following is the description: 1. Codes in Wandiundiu folklore, semiotic study, are related to the study of signs and everything related to signs, such as the sign system and processes that apply to sign users (Zoest, 1993: 1). Based on the results of research conducted by researchers on the folklore text Wandiu-ndiu using Roland Barthes' semiotic analysis. Understanding Roland Barthes' code will make it easier for readers to assess the connotation level of a text (Paliang, 2003: 169). The results of this study indicate that there are five codes in the folklore text of Wandiu-ndiu, in terms of 1) hermeneutic code, 2) proairetic / action code, 3) semic / connotative code, 4) symbol code, and 5) cultural code. The following are the results of the analysis for each code found in this study. Hermeneutic code is a code consisting of sign units that function to articulate dialectics in the form of response questions but the answers or conclusions of the word or sentence are postponed, causing puzzles or creating mystery in the story or literature (Safiuddin, 2019)

Semiotic study deals with the assessment of signs and everything related to signs, such as sign systems and processes that apply to sign users (Zoest, 1993: 1). In the study of the image of Wolio women, the researcher also linked several semiotic signs to help analyze the meaning of the I folklore text by using Roland Barthes' semiotic analysis. Understanding Roland Barthes' code will make it easier for readers to assess the connotation level of a text (Paliang, 2003: 169).

In this study, researchers found the first form of code, namely the hermeneutic code. Hermeneutic code is a code consisting of sign units which function to articulate a dialectic in the form of response questions, but the answers or conclusions of the word or sentence are 
postponed, causing puzzles or creating mystery in the story or literature. In I folklore, the code found is "I in the title which means mermaid. The word I is categorized into a hermeneutic code or puzzle code because reading it will raise the question, whether the mermaid in question is really a real mermaid or the incarnation of someone who becomes a mermaid.

In I text, there are several proairetic codes that can help this research as a preliminary study to see the meaning of aspects of the image of Wolio women, including the following:

\subsection{The Image of Wolio Woman in The Public}

In her role as a woman in the public space, Wolio's folklore provides many interesting imagery. To see the representation of Wolio women, it can be traced in various folk tales. Even in the writing tradition (script) of the modern generation, it is found that one of the roles of Wolio women in folklore is imaged as a supporting woman as queen, namely the first queen of Buton and the second queen of Buton. Wakaaka and Bulawambona are two queen figures which had known as a wise and brilliant leader in their moments.

\subsubsection{The Image of Wolio Woman as a Queen}

The image of Wolio women in the eyes of society is currently considered the same as other societies. However, in the kingdom era, the two queens of Wakaakaa and Bulawambona were Queen Buton who was highly respected and admired as leader who were just, wise, intelligent in government strategy and politics, and wise in taking bureaucratic policies.

In the eyes of society, the image of Wolio women is not only depicted as someone who only contributes to the domestic aspect. However, Wolio women have long had the potential to be able to take strategic roles in the local and global world. In fact, in the days of the Buton kingdom as well as in modern times, Wolio women generally received a good education and could enter the Zawiyah madrasah, many Tarikat scholars in Wolio came from among young women who had qualified intellectual talents, for example by writing a book, for example Wa Ode Samarati Fuadi bint Sultan Muhammad Aidrus, with the phenomenal book Kanturuna Molingkana. This shows that Wolio women have the ability to occupy public spaces as in the folklore Hikayat Negeri Buton. The reading from a socio-feminist perspective shows that the folklore of Wolio (Buton) has room to construct an image of oppressed women such as the wandiu-ndiu dongeng, but instead tells about the roles of women as queens. This shows that the folklore of Wolio (Buton) constructs the image of women in the public space who are able to act as queens.

If you look further, Kaomu and Walaka are two symbols, respectively pinned to those with aristocratic status and for those who are ordinary citizens outside the kingdom. However, these two statuses have almost equal access in the world of education and the world of work, for example, Mrs. Zainab bint Maa Sauda was the first woman to become a teacher (in 1940) from the Walaka group (a class of people with a caste outside the Wolio kingdom) where at that time there were no teachers from the kaomu group (royal royal class) and he roughly died 3 years ago at the age of more than 90 years. According to the bureaucratic view, the status of kaomu and walaka is a status pinned for the benefit of division of tasks, you take over executive duties, while walaka take on legislative functions (siolimbona, or what is known as the House of Representatives which consists of 9 people) in charge of appointing a king and or the royal queen during the sultanate.

Even in the government system, the Sultanate of Buton recognizes the means of bhawine (sara Perempuan) as a place to represent Buton's women's role in government. This shows that Buton women are not only portrayed as weak women, but in the folklore around the Buton palace, many great Buton women are told, even including in the economic world, they know Wa Ode Wau who has enormous wealth. the usual. An amazing oral history story about 
women's control over various royal assets in the past. Thus, Buton women in the public sphere are imaged as women who have access to the world of education, economy, politics and culture, which is the same as men.

\subsubsection{The Image of Wolio Woman in Modern Era}

Wolio women in this modern era have served significant functions in the public sphere and have filled strategic positions in the bureaucracy, service offices, formal and non-formal institutions, dakwah institutions, religious institutions, and others. They are no longer confined in a domestic space like a house and a kitchen in a narrow sense. Many Wolio women have become representatives of their people to become leaders in an educational institution such as a campus or community, certain organizations and even become leaders in the highest state bureaucracy. However, it is not uncommon for Wolio women to also be positioned as the second being (the second sex). This fact appears to be still emerging in the context of regional leadership. For example, in the legislative and executive leadership, they are best positioned not to occupy the highest position or even not in any position because political stakes are very complex and often fierce. Women are still considered to have no male character such as brave and strong which is considered the potential to become leaders.

\subsection{The Fundamental Ideology Underlying Wolio Woman's Image}

Marginalization is an action that places wolio women to limit all forms of activity and creativity of a woman. Wolio women are portrayed as weak, lacking or courageous, so they are inappropriate or unable to lead. It can be seen that wolio women are creatures who do not have the right to vote differently from men who are free to choose.

So far, what has happened is a social condition that emphasizes the role of men. Women are marginalized who are always marginalized and displaced. The emancipation of women that has been struggling has helped women to exist more or less, but women are still bound to patriarchal norms which are very binding and make wolio women try extra hard to find positions and make their duties and roles so numerous. This problem actually rests on the inequality of roles and burdens between men and women. Labeling men and women as partners, women are always marginalized because of their female status. This is also highly supported and evenly adopted by the concept of patriarchy in almost all societies.

Patriarchy is a social system that places men as the main power holders and dominates in perceptions of political leadership, moral authority, social rights and property control. In the family domain, the figure called the father has authority over women, children and property. Some patriarchal societies are also patrilineal, meaning that property and titles are passed on to male descendants. Implicitly, this system is enforced in the government and the privileges of men and places wolio women under men.

In this case, wolio women are placed in the domestic area or in the story, they are placed in kitchen work, while the skipper figures are placed in the public sector or areas outside the kitchen. The marginalization process that occurs in Wolio female characters creates boundaries between women and men. That women only have a place in the house area and men only have a place in the public domain.

In carrying out daily activities, especially roles in the domestic and public areas, there are also expressions that position women and men in Southeast Sulawesi, especially among the Wolio area. In the domestic area, it is found that the female domain surrounds the house, and especially for the public area, it is found that male dominance reaches the limit of the sky.

Marginalization also occurs because of the many stories that women have debts to men. Telling that in general women were created from the bent ribs belonging to men. So women 
should serve men because of their debt. In addition, the depiction of the creator and messengers symbolized as men makes the position of women weaker.

\subsection{Subordination}

Subordination is an assumption that women are irrational or emotional so that women cannot appear to lead, resulting in an attitude that places women in an insignificant position. Because of their feminine nature, women need the protection of masculine men. Then emerged the domination of men over women, both in household life and in the public world. In domestic life, men or husbands with masculine characteristics are placed by culture as the head of the household, while women are the second person.

In wolio women is positioned as an ordinate or positioned as a dominating figure, and the skipper figure is positioned as a subordinate or a dominating figure.

The change in the position of wolio women who became the ordinate point or dominating and men as subordinate was used as a way for wolio women to do their goal. That wolio women can leave demostics where they are controlled by men. Men think that women should be in a subordinate position, but instead have a higher position. In the view of men, women have changed the structure in the patriarchal culture, including women who have participated in decision making which was originally the realm of men. Even women have participated in giving opinions like Wolio women who have succeeded in giving consideration to the skipper figures who want to follow her wishes.

\subsection{Stereotypes}

Women are imaged or stereotyped by many people with a gentle, motherly attitude. However, the female characters here have a tendency far from this attitude. Female characters are stereotyped as being flirtatious, and also like to flirt with boys. The easily seduced man easily becomes entangled in tricks.

In general, stereotypes are labeling. This labeling always results in injustice, so it is called negative labeling. This is due to the inherent male and mighty labeling. Meanwhile, women are creatures that are beautiful, emotional, and motherly.

\section{Conclusion}

The image of women in Buton folklore depicts the role of women in the domestic and in the public sphere, which has almost equal responsibilities. A Wolio woman must be able to have a role in the domestic space, as mother, wife and child, while still paying attention to cultural values and still being a woman who has a balanced role, both in the domestic and in the public space as well.

In a modern context, Wolio (Buton) women have a bigger space to play roles in both the domestic and public spaces. They get the opportunity to become good wives by following their husbands, obeying their husbands and being able to build hopes and ideas with their husbands to build their households democratically through sustainable dialogue. In the public space, they still get access without forgetting their roles in the domestic space, because breastfeeding is a space to maintain children's health and maternal health simultaneously.

Ideologically, the role of women imaged in various folk tales is based on the Buton culture which supports the development of Wolio (Buton) women both in the domestic and public. Various folk stories support the role of women to vote, as subordinated women or women who have strategic roles both in the domestic and in the public circumstances. 


\section{References.}

[1] Brown, M. E., Hesse, E., Ruthven, K. K., Schneidau, H. N., \& Witemeyer, H. (1971). New Approaches to Ezra PoundA Guide to Ezra Pound's Personae (1926)Ezra Pound: The Image and the RealThe Poetry of Ezra Pound: Forms and Renewals, 1908-1920. The Journal of Aesthetics and Art Criticism. https://doi.org/10.2307/428986

[2] Desi Sari, Sumiman Udu, L. I. (2019). Kekerasan Terhadap Perempuan Dalam Novel Savannah Karya Ima Lawaru: Kritik Sastra FEMINIMSE. Jurnal Pendidikan Bahasa.

[3] Fitriani, N., Qomariyah, U., \& Sumartini, S. (2019). Citra Perempuan Jawa Dalam Novel Hati Sinden Karya Dwi Rahyuningsih: Kajian Feminisme Liberal. Jurnal Sastra Indonesia, 7(1), 62-72. https://doi.org/10.15294/jsi.v7i1.29818

[4] Gafur, A. (2015). Pendekatan Feminis Dalam Kajian Islam. Al-Tatwir, 2(1), 153174.

[5] Hindaryatiningsih, N. (2016). Model Proses Pewarisan Nilai-Nilai Budaya Lokal Dalam Tradisi Masyarakat Buton. Sosiohumaniora. https://doi.org/10.24198/sosiohumaniora.v18i2.9944

[6] Hasibuan, L. (2018). Antara Emansipasi Dan Peran Ganda Perempuan (Analisa Fakta Sosial Terhadap Kasus Ketimpangan Gender). Hikmah, 11(2).

[7] Herawati, Y. (2013). Citra Perempuan dalam Novel Upacara, Api Awan Asap, dan Bunga Karya Korrie Layun Rampan. ATAVISME, 16(1), 43-56. http://puslit2.petra.ac.id/ejournal/index.php/dkv/article/view/16072 https://doi.org/10.24257/atavisme.v16i1.80.43-56 https://doi.org/10.24952/hik.v11i2.752 https://doi.org/10.30998/deiksis.v12i01.3796 https://www.researchgate.net/publication/320097616 PEREMPUAN DAL M_CITRA KETIDAKADILAN_GENDER_Kajian_Feminis_dan_Resepsi tas Kisah Yusuf dalam Serat Yusuf

[8] Isenberg, A., \& Abrams, M. H. (1954). The Mirror and the Lamp: Romantic Theory and the Critical Tradition. The Journal of Aesthetics and Art Criticism. https://doi.org/10.2307/426915

[9] Isma, M., \& Gazali, H. (2016). Perempuan dalam Citra Ketidakadilan Gender (Kajian Feminis dan Resepsi atas Kisah Yusuf dalam Serat Yusuf). Jurnal Muwazah, 8(2), 201-223. Retrieved from

[10] Martadi Martadi. (2001). CITRA PEREMPUAN DALAM IKLAN DI MAJALAH FEMINA EDISI TAHUN 1999 Kajian Semiotik Terhadap Nilai-nilai Gender Dalam Desain Iklan. Nirmana, 3(2). Retrieved from

[11] Mulyadi, B. (2018). Menyibak Citra Perempuan Dalam Cerpen "Maria " ( Sebuah Kajian Sastra Feminisme ). Humanika, 25(2), 88. https://doi.org/10.14710/humanika.v25i2.20761

[12] Mustikawati, C. (2015). Pemahaman Emansipasi Wanita (Studi Hermeneutika Makna Emansipasi Wanita Dalam Pemikiran R. A. Kartini Pada Buku Habis Gelap Terbitlah Terang). Jurnal Kajian Komunikasi, 3(1), 65-70.

[13] Salmatian Safiuddin (2019), "Analisis Semiotika Pada Cerita Rakyat Wandiu-Ndiu The Semiotic Analysis of Wandiu-Ndiu Folklore”, Jurnal Lakon, 8 (2) 2019 (78-86) 78 Jurnal Lakon: Kajian Sastra dan Budaya e-ISSN: 2527-4899; p-ISSN, Program Studi Magister Kajian Sastra dan Budaya Fakultas Ilmu Budaya Universitas Airlangga J1. Dharmawangsa Dalam Selatan, Surabaya 60286 e-mail: 
salmatian.safiuddin-2018@fib.unair.ac.id

[14] Syahrul, N. (2017). Citra Perempuan Dalam Kaba Anggun Nan Tungga Karya Ambas Mahkota. Jentera: Jurnal Kajian

Sastra, 2(2).https://doi.org/10.26499/jentera.v2i2.407

[15] Udu, S. (2010). Perempuan dalam kabnati: Tinjauan Sosiofeminis (La Ode Simono (ed.); 1st ed.). Yogyakarta: CV Diandra.

[16] Udu, S. (2019a). Peran Perempuan dalam Pembangunan Buton Raya. In Academia.edu. https://doi.org/10.1017/CBO9781107415324.004

[17] Udu, S. (2019b). Wowine Dalam Kebudayaan Maritim Wakatobi Buton: AnalisisPierre Bourdieu. Sasdaya: Gadjah Mada Journal of Humanities. https://doi.org/10.22146/sasdayajournal.31743 